\title{
ANALISIS KINERJA KEUANGAN SEBAGAI DASAR INVESTOR DALAM MENANAMKAN MODAL PADA PT. BUKIT ASAM,TBK
}

(Study Kasus pada PT. Bukit Asam,TBK)

\author{
Farida Efriyanti, Universitas Bandar Lampung \\ Retno Anggraini, Universitas Bandar Lampung \\ Yunus Fiscal, Universitas Bandar Lampung
}

\begin{abstract}
Researchers conducted the study on PT. Bukit Asam Tbk, a company engaged in coal. In running the business of PT. Bukit Asam Tbk facing problems in measuring the achievements of the company based on the financial ratios of liquidity, solvency, activity and profitability. Over the last three years ie during the years 2009-2011. Rumussn problem is: "whether the financial performance affects investor in menananmkan mdal on PT.Bukit Acid, Tbk"?

The purpose of this study the researchers did was to analyze the performance of keuanagn as the investor base to invest in PT.Bukit Acid, Tbk. Based on the analysis conducted by the authors, financial performance PT.Bukit Acid, Tbk terms of the ratio of liquidity, solvency, activity and profitability over the last three years increased. Suggestions submitted by the author is to maintain and improve the company's financial performance PT.Bukit Asam Tbk enable companies to more forward.
\end{abstract}

Keywords: Analysis Financial Performance, Basis Capital Investors

\section{LATAR BELAKANG}

Perusahaan merupakan organisasi yang mencari keuntungan sebagai tujuan utamanya walaupun tidak menutup kemungkinan mengharapkan kemakmuran sebagai tujuan lainnya. Di samping itu ada pula tujuan lain yang tidak kalah penting yaitu dapat terus bertahan dalam persaingan, berkembang serta dapat melaksanakan fungsi-fungsi sosial lainnya di masyarakat. Para pelaku bisnis melakukan pengambilan keputusan ekonomi, membutuhkan informasi tentang kondisi dan kinerja perusahaan .

Untuk mempertahankan kelangsungan hidup di tengah kerasnya persaingan bisnis yang ketat, perusahaan haruslah memilih strategi yang terintegrasi dengan baik sesuai dengan karakter perusahaan. Perusahaan yang tepat memilih strategi akan dapat mempertahankan dan mengungguli persaingan dalam pertumbuhan dan perolehan laba serta mampu bertahan dalam siklus kehidupan bisnis dalam jangka waktu yang cukup panjang. Kondisi keuangan perusahaan merupakan salah satu faktor yang penting di dalam penilaian bagi investor. Hal ini karena di dalamnya sudah tercakup asset dan tingkat kemampuan laba yang diperoleh perusahaan. Dalam hal ini asset diperlukan untuk digunakan sebagai sarana (aktiva produksi) untuk memperoleh laba dan mempertahankan kelangsungan hidup perusahaan.

Untuk melihat kondisi dan perkembangan suatu perusahaan, biasanya akan membuat penyusunan laporan keuangan yang menggambarkan kejadian-kejadian atau segala transaksi yang terjadi di perusahaan yang kemudian digunakan untuk menganalisis kinerja keuangan pada perusahaan tersebut.

Penilaian kinerja keuangan merupakan salah satu cara yang dapat dilakukan oleh pihak manajemen agar dapat memenuhi kewajibannya terhadap para penyandang dana dan juga untuk mencapai tujuan yang telah ditetapkan oleh perusahaan. Cara untuk mengetahui baik buruknya kinerja keuangan dalam suatu perusahaan dapat diketahui dengan cara menganalisis hubungan dari berbagai 
pos dalam suatu laporan keuangan. Pengukuran kinerja keuangan dapat dilakukan menggunakan rasio keuangan. (Husnan, 2003). Adapun alat analisis kinerja keuangan pada perusahaan yang digunakan meliputi rasio likuiditas, rasio solvabilitas, rasio profitabilitas (rentabilitas), rasio aktivitas. Analisis rasio keuangan merupakan metode analisis yang sering dipakai karena merupakan metode yang paling cepat untuk mengetahui kinerja keuangan PT. Bukit Asam Tbk. Dengan mengetahui kinerjanya, PT. Bukit Asam Tbk akan dapat melakukan perkiraan keputusan apa yang akan diambil guna mencapai tujuannya. Analisis rasio keuangan pada PT. Bukit Asam akan menyederhanakan informasi yang menggambarkan hubungan antara pos-pos tertentu dengan pos lainnya yang dilaporkan. Dalam hal ini analisis rasio keuangan pada PT. Bukit Asam Tbk akan menggali informasi dari laporan neraca dan laporan hasil usahanya.

Saham merupakan salah satu alternatif dalam aset finansial. Kebutuhan akan informasi yang relevan dalam pengambilan keputusan investasi dalam aset finansial di pasar modal sangat dibutuhkan oleh investor. Suatu pendekatan dalam menganalisis harga saham dipasar modal yang dapat membantu investor dalam membuat keputusan investasi adalah pendekatan fundamental dan teknikal. Pendekatan secara fundamental mendasarkan analisanya pada suatu anggapan bahwa setiap saham mempunyai nilai intrinstik dihasilkan. Salah satu indikator yang dapat digunakan yaitu apabila semakin rendah harga suatu saham maka semakin bagus untuk melakukan investasi, hal tersebut dikarenakan harga saham dapat terjangkau oleh kemampuan investor dan memiliki nilai resiko yang kecil.

\section{TELAAH LITERATUR DAN PENGEMBANGAN HIPOTENSI}

\subsection{Kinerja Keuangan}

Menurut mulyadi (2001:415) penilaian kinerja adalah penentuan secara periodik afektivitas operasional suatu organisasi, bagian organisasi dan karyawannya berdasarkan sasaran, standar dan kriteria yang telah ditetapkan sebelumnya . Kinerja perusahaan merupakan kata umum untuk menggambarkan keberhasilan atau kesuksesan suatu perusahaan. Kinerja yang baik menunjukkan bahwa perusahaan dikelola dengan baik . Dalam operasional dunia usaha kerja perusahaan dapat dirumuskan sebagai hasil kerja yang diperoleh atas kegiatan atau operasi yang dilakukan oleh perusahaan selama periode waktu tertentu, dan laba merupakan salah satu tolak ukur penting dalam penilaian kinerja perusahaan (standar akuntansi keuangan, 2001)

Karena organisasi pada dasarnya dijalankan oleh manusia, maka penilaian sesungguhnya merupakan penilaian atas prilaku manusia melaksanakan peran yang mereka mainkan didalam organisasi dan karyawannnya berdasarkan sasaran, standar dan kriteria yang telah ditetapkan sebelumnya.

Berdasarkan pengertian di atas, kinerja keuangan adalah mengelola operasional keuangan secara efektif dan efisien dalam upaya mencari laba usaha optimal. Penilaian kinerja keuangan itu sendiri berkaitan erat dengan informasi akuntansi . Akuntasi dapat memberikan informasi tentang kondisi keuangan dan hasil operasi saat kinerja keuangan perusahaan, seperti tercermin dalam laporan keuangan dapat digunakan sebagai alat komunikasi bagi pihak-pihak yang berkepentingan dalam laporan keuangan tersebut. Pada umumnya perusahaan yang mampu mengelola peruahaan secara efektif dan efisien maka kinerja perusahaannya akan semakin baik, sehingga tingkat keuntungan yang dicapai akan semakin tinggi.

\subsection{Tujuan Dan Manfaat Penilaian Kinerja Perusahaan}

\subsubsection{Tujuan Penilaian Kinerja Perusahaan}

Penilaian kinerja merupakan suatu hal yang penting dalam proses perencanaan dan pengendalian melalui penilaian kinerja, perusahaan dapat melakukan perencanaan dan dapat memilih strategi yang dapat dilaksanakan dalam mencapai tujuan yang telah ditetapkan secara umum. Disamping tujuan-tujuan di atas, pengukuran kinerja mempunyai manfaat bagi manajemen untuk 
menciptakan organisasi yang efektif dan efisien. Menurut munawir (2002:31) tujuan dari penilaiaan kinerja perusahaan adalah :

1. Untuk mengetahui tingkat likuiditas, yaitu perusahaan memenuhi kewajiban keuangan saat ditagih.

2. Untuk mengetahui tingkat solvabilitas, yaitu kemampuan perusahaan untuk memenuhi kewajiban keuntungannya apabila perusahaan tersebut dilikuiditasi baik kewajiban keuangan jangka pendek maupun jangka panjang.

3. Untuk mengetahui tingkat profitabilitas, yaitu suatu kemampuan perusahaan untuk menghasilkan laba periode tertentu.

4. Untuk mengetahui stabilitas usaha, yaitu kemampuan perusahaan untuk melakukan usahanya dengan stabil dan mempertimbangkan perusahaan untuk membayar deviden secara teratur.

Penilaian kinerja dilakukan untuk menekankan prilaku semestinya dan untuk menegakkan prilaku yang semestinya diinginkan melalui umpan balik hasil kinerja pada waktu penghargaan.

\subsubsection{Manfaat Penilaian Kinerja Perusahaan}

Manfaat dari penilaian kinerja perusahaan adalah sebagai berikut :

1. Untuk mengukur pretasi yang dicapai oleh suatu organisasi dalam suatu periode tertentu yang mencerminkan tinhkat keberhasilan pelaksanaan kegiatannya .

2. Selain digunakan untuk melihat kinerja organsisasi secara keseluruhan, maka pengukuran kinerja juga dapat digunakan untuk menilai kontribusi suatu bagian dalam pencapaian tujuan secara keseluruhan .

3. Dapat digunakan sebagai dasar penentuan strategi perusahaan untuk masa yang akan datang .

4. Memberi petunjuk dalam pembuatan keputusan dan kegiatan organisasi pada umumnya dan divisi atau bagian organisasi pada khususnya.

5. Sebagai dasar penentuan kebijaksanaan penanaman mdal aga dapat meningkatkan efisiensi dan produktivitas perusahaan .

\subsection{Pengukuran Kinerja Keuangan}

Ada tiga macam pengukuran kinerja keuangan adalah :

a. Ukuran kinerja tunggal

Ukuran kriteria tunggal(single criteria) adalah ukuran kinerja yang hanya menggunakan satu ukuran untuk menilai kinerja manajer. Kelemahan apabila kriteria tunggal digunakan untuk mengukur kinerja yaitu orang yang akan cenderung memusatkan usahanya pada kriteria pada usaha tersebut sehingga akibatnya kriteria lain diabaikan .

b. Ukuran kriteria beragam

Ukuran kriteria beragam (multiple criteria) adalah ukuran kinerja yang menggunakan berbagai macam ukuran untuk menilai kriteria manajer. Tujuan penggunaan beragam ini adalah agar manajer. Tujuan penggunaan beragam ini adalah agar manajer yang dikukur kinerjanya mengarahkan usahanya kepada berbagai kinerja .

c. Ukuran kriteria gabungan

Ukuran kriteria gabungan (composite criteria) ukuran kinerja yang menggunakan berbagai macam ukuran, ukuran memperhitungkan bobot masing-masing ukuran dan menghitung rata-ratanya sebagai ukuran yang menyeluruh kinerja manajer . 


\subsection{Laporan Keuangan}

Menurut Ikatan Akuntan Indonesia (IAI), dalam PSAK No.1 Paragraf 07: Laporan Keuangan merupakan bagian dari proses pelaporan keuangan. Laporan keuangan yang lengkap biasanya meliputi neraca, laporan laba rugi, laporan perubahan posisi keuangan, catatan dan laporan lain serta materi penjelasan yang merupakan bagian intergral dari laporan keuangan.

Menurut Zaki Baridwan dalam bukunya "intermediate accounting” (2004;17) pengertian laporan keuangan adalah: "Ringkasan dari transaksi-transaksi keuangan yang terjadi selama satu tahun buku yang bersangkutan". Laporan keuangan pada dasarnya adalah hasil dari proses akuntansi yang dapat digunakan sebagai alat untuk berkomunikasi antara data keuangan atau aktivitas suatu perusahaan dengan pihak-pihak yang berkepentingan dengan data atau aktivitas perusahaan tersebut .

\subsubsection{Tujuan Laporan Keuangan}

Menurut APB Statement No.4 APB Statement No.4 berjudul Basic Concepts and Accounting Principles Underlying Financial Statement Bussiness Enterprises. Laporan ini bersifat deskriptif, dan laporan ini banyak mempengaruhi studi-studi berikutnya tentang tujuan laporan keuangan. Dalam laporan ini tujuan laporan keuangan digolongkan sebagai berikut:

1. Tujuan Khusus

Tujuan khusus dari laporan keuangan adalah untuk menyajikan laporan posisi keuangan, hasil usaha, dan perubahan posisi keuangan lainnya secara wajar dan sesuai dengan GAAP.

2. Tujuan umum

Adapun tujuan umum laporan keuangan disebutkan sebagai berikut:

a. Memberikan informasi yang terpercaya tentang sumber-sumber ekonomi dan kewajiban perusahaan dengan maksud:

- Untuk menilai kekuatan dan kelemahan perusahaan

- Untuk menunjukan posisi keuangan dan investasinya

- Untuk menilai kemampuannya untuk menyelesaikan utang-utangnya

- Menunjukan kemampuan sumber-sumber kekayaannya yang ada untuk pertumbuhan perusahaan.

b. Memberikan informasi yang terpercaya tentang sumber-sumber kekayaan bersih yang berasal dari kegiatan usaha dalam mencari laba dengan maksud:

- Memberikan gambaran tentang deviden yang diharapkan pemegang saham

- Menunjukan kemampuan perusahaan untuk membayar kewajiban kepada kreditor, supplier, pegawai, pajak, mengumpulkan dana untuk perluasan perusahaan

- Memberikan informasi kepada manajemen untuk digunakan dalam pelaksanaan fungsi perencanaan dan pengawasan.

- Menunjukan tingkat kemampuan perusahaan mendapatkan laba dalam jangka panjang.

c. Menaksirkan informasi keuangan yang dapat digunakan untuk menaksir potensipotensi perusahaan dalam menghasilkan laba.

d. Memberikan informasi yang diperlukan lainnya tentang perubahan harta dan kewajiban.

e. Mengungkapkan informasi relevan lainnya yang dibutuhkan para pemakai laporan. 
3. Tujuan Kualitatif

Adapun tujuan kualitatif yang dirumuskan APB Statement No.4 adalah sebagai berikut:

1) Relevance

Memilih informasi yang benar-benar sesuai dan dapat membantu pemakai laporan keuangan dalam proses pengambilan keputusan.

2) Understandability

Informasi yang dipilih untuk disajikan bukan saja yang penting tetapi juga harus informasi yang dimengerti para pemakainya.

3) Verifiability

Hasil akuntansi itu harus dapat diperiksa oleh pihak lain yang akan menghasilkan pendapat yang sama.

4) Neutrality

Laporan akuntansi itu netral terhadap pihak-pihak yang berkepentingan. Informasi dimaksudkan untuk pihak umum bukan pihak-pihak tertentu saja.

5) Timeliness

Laporan akuntansi hanya bermanfaat untuk pengambilan keputusan apabila diserahkan pada saat yang tepat.

6) Comparability

Informasi akuntansi harus dapat saling dibandingkan, artinya akuntansi harus memiliki prinsip yang sama baik untuk suatu perusahaan maupun perusahaan lain.

7) Completeness

Informasi akuntansi yang dilaporkan harus mencakup semua kebutuhan yang layak dari para pemakai.

\subsubsection{Manfaat Laporan Keuangan}

1. Untuk mengukur prestasi yang dicapai oleh suatu organisasi dalam suatu periode tertentu yang mencerminkan tingkat keberhasilan pelaksanaan kegiatannya.

2. Selain digunakan untuk melihat kinerja organisasi secara keseluruhan, maka pengukuran kinerja juga dapat digunakan untuk menilai kontribusi suatu bagian dalam pencapaian tujuan perusahaan secara keseluruhan.

3. Dapat digunakan sebagai dasar penentuan strategi perusahaan untuk masa yang akan datang.

4. Memberi petunjuk dalam pembuatan keputusan dan kegiatan organisasi pada umumnya dan divisi atau bagian organisasi pada khususnya.

5. Sebagai dasar penentuan kebijaksanaan penanaman modal agar dapat meningkatkan efisiensi dan produktivitas perusahaan.

Menurut PSAK (2009) pihak-pihak yang memanfaatkan laporan keuangan adalah (IAI,2004):

1. Investor.

Penanam modal berisiko dan penasehat mereka berkepentingan dengan risiko yang melekat serta hasil pengembangan dari investasi yang mereka lakukan. Mereka membutuhkan informasi untuk membantu menentukan apakah harus membeli, menahan atau menjual investasi tersebut..

2. Karyawan.

Karyawan dan kelompok-kelompok yang mewakili mereka tertarik pada informasi mengenai stabilitas dan profitabilitas perusahaan. Mereka juga tertarik dengan informasi yang memungkinkan mereka untuk menilai kemampuan perusahaan dalam memberikan balas jasa manfaat pensiun dan kesempatan kerja.

3. Pemberi pinjaman.

Pemberi pinjaman tertarik dengan informasi keuangan yang memungkinkan mereka untuk memutuskan apakah pinjaman serta bunga dapat dibayar pada saat jatuh tempo. 
4. Pemasok dan kreditur usaha lainnya.

Pemasok dan kreditur usaha lain tertarik dengan informasi yang memungkinkan mereka untuk memutuskan apakah jumlah yang terhutang akan dibayar pada saat jatuh tempo. Kreditur usaha berkepentingan pada perusahaan dalam tenggang waktu yang lebih pendek daripada pemberi pinjaman kecuali kalau sebagai pelanggan utama mereka tergantung pada kelangsungan hidup perusahaan.

5. Pelanggan.

Para pelanggan berkepentingan dengan informasi mengenai kelangsungan hidup perusahaan terutama kalau mereka terlibat dalam perjanjian jangka panjang dengan atau tergantung pada perusahaan.

6. Pemerintah.

Pemerintah dan berbagai lembaga yang berada di bawah kekuasaan berkepentingan dengan alokasi sumber daya dan karena ini berkepentingan dengan aktivitas perusahaan mereka menetapkan kebijakan pajak dan sebagai dasar untuk menyusun statistik pendapatan nasional dan statistik lainnya.

7. Masyarakat.

Perusahaan mempengaruhi anggota masyarakat dalam berbagai cara. Misal perusahaan dapat memberikan kontribusi berarti pada perekonomian nasional termasuk jumlah orang yang dipekerjakan dan perlindungan kepada penanam modal domestik. Laporan keuangan dapat membantu masyarakat dengan menyediakan informasi kecenderungan (trend) dan perkembangan terakhir kemakmuran perusahaan serta rangkaian aktivitasnya

\subsubsection{Jenis-jenis Analisis Laporan Keuangan}

Ada beberapa jenis analisa yang dapat dilakukan, yaitu:

1. Analisa Horisontal adalah analisa perkembangan data keuangan dan data operasi perusahaan dari tahun ke tahun guna mengetahui kekuatan atau kelemahan keuangan perusahaan yang bersangkutan. Analisis ini terdiri dari Comparative Statements dan Index Number Series

2. Analisa Vertikal adalah analisa laporan keuangan yang terbatas hanya pada satu periode akuntansi saja. Analisis ini terdiri dari Common Size Financial Statement dan Ratio Analysis

\subsubsection{Teknik Analisis Laporan Keuangan}

Beberapa teknik analisis laporan keuangan dapat disebutkan sebagai berikut:

1. Analisis Perbandingan

Analisis perbandingan adalah teknik analisis laporan keuangan yang dilakukan dengan cara menyajikan laporan keuangan secara horizontal dan membandingkan antara satu dengan yang lain, dengan menunjukan informasi keuangan atau data lainnya baik berupa rupiah atau dalam unit.

2. Analisis Trend

Analisis trend ini bertujuan untuk mengetahui tendensi atau kecendrungan keadaan suatu perusahaan di masa yang akan datang baik kecendrungan naik, turun maupun tetap.

3. Common size

Teknik common size menggunakan pola atau teknik penyederhanaan angka dalam laporan keuangan. Analisis laporan keuangan dengan teknik ini memerlukan angka dasar sebagai dasar perhitungan konversi, untuk neraca biasanya menggunakan total aktiva atau total pasiva sebagai dasar dengan angka $100 \%$.

4. Analisis Rasio keuangan

Analisis rasio adalah suatu metode analisis untuk mengetahui hubungan dari pos-pos tertentu dalam neraca atau laporan laba rugi secara individu atau kombinasi dari kedua laporan tersebut. 
Kegunaan rasio keuangan keuangan bagi kelompok utama pemakai laporan keuangan adalah sebagai berikut :

a. Manajer yang menerapkan rasio untuk membantu menganalisis, mengendalikan, dan kemudian meningkatkan operasi perusahaan.

b. Analisis kredit, temasuk peugas pinjaman bank dan analisis peringkat obligasi, yang menganalisis rasio-rasio untuk membantu memutuskan kemampuan kemampuan erusahaan untu membayar utang-utangnya

c. Analisis saham, yang tertarik pada efisiensi, resiko, dan prospek pertumbuhan perusahaan.

Analisis rasio keuangan memiliki beberapa keungguan sebagai alat analisis :

1. Keunggulan Analisis Rasio

Analisis rasio ini mempunyai keunggulan dibanding dengan teknik analisis lainnya. Keunggulan tersebut adalah :

- Rasio merupakan angka-angka atau ikhtisar statistik yang lebih mudah dibaca dan ditafsirkan.

- Merupakan pengganti yang lebih sederhana dari informasi yang disajikan laporan keuangan yang sangat rinci dan rumit.

- Mengetahui posisi perusahaan ditengah industri lain.

- Sangat bermanfaat untuk bahan dalam mengisi model-model pengambilan keputusan dan model prediksi.

- Menstandarisir size perusahaan.

- Lebih mudah membandingkan perusahaan dengan perusahaan yang lainnya secara periodik.

- Lebih mudah melihat trend perusahaan serta melakukan prediksi dimasa yang akan datang.

2. Keterbatasan Analisis Rasio

Disamping keunggulan dari teknik ini,teknik ini juga mempunyai beberapa keterbatasan,yaitu sebagai berikut :

- Kesulitan dalam memilih rasio yang tepat yang dapat digunakan untuk kepentingan pemakai.

- Keterbatasan yang dimiliki akuntansi atau laporan keuangan juga menjadi keterbatasan teknik ini seperti :

- Bahan perhitungan rasio atau laporan keuangan itu banyak mengandung taksiran dan judgment yang dapat dinilai bias atau subyektif.

- Nilai yang terkandung dalam laporan keuangan dan rasio adalah nilai perolehan (cost) bukan harga pasar.

- Klasifikasi dalam laporan keuangan bias berdampak pada angka rasio.

- Jika data untuk menghitung rasio tidak tersedia maka akan menimbulkan kesulitan menghitung rasio.

- Sulit jika data yang tersedia tidak sinkron.

- Jika dua perusahaan dibandingkan bisa saja teknik standar akuntansi yang dipakai tidak sama. 
3. Pengolongan Angka Rasio

Menurut S. Munawir (2004:68), Berdasarkan sumber datanya, angka rasio dapat dibedakan menjadi:

- Rasio-rasio Neraca (Balance Sheet Ratios) yang tergolong dalam kategori ini adalah semua rasio yang semua datanya diambil atau bersumber pada neraca, misalnya current ratio, acid test ratio

- Rasio-rasio Laporan Laba Rugi (Income Statement Ratios) yaitu angka-angka rasio yang dalam penyusunannya semua datanya diambil dari Laporan Laba Rugi, misalnya gross profit margin, net operating margin, operating ratio dan lain sebagainya

- Rasio-rasio antar Laporan (interstatement ratios) ialah semua angka rasio yang penyusunan datanya berdasar dari neraca dan data lainnya dari laporan Laba Rugi, misalnya tingkat perputaran persediaan (inventory turn over), tingkat perputaran piutang (account receivable turn over), sales to inventory, sales to fixed asset dan lain sebagainya.

\section{METODOLOGI PENELITIAN}

\subsection{Objek Penelitian}

PT. Bukit Asam,Tbk Tanjung Enim. Laporan Keuangan dari tahun 2009 sampai tahun 2011.

\section{Jenis dan Sumber Data}

Penelitian ini menggunakan data sekunder. Data Sekunder yaitu data yang diperoleh peneliti secara tidak langsung melalui media perantara (diperoleh dan dicatat oleh pihak lain) yaitu melalui media cetak dan internet yang berhubungan dengan permasalahan penelitian. Data sekunder umumnya berupa bukti, catatan atau laporan yang telah tersusun dalam arsip (data dokumen) yang dipubikasikan. Sumber data yaitu annual report PT. Bukit Asam Tbk diperoleh dari Bursa Efek Jakarta.

\subsection{Metode Analisis Data}

Analisis yang digunakan dalam penelitian ini adalah :

a. Analisis kuantitatif

Analisis kuantitatif adalah suatu analisis yang dilakukan dengan cara perhitungan dengan menggunakan data-data yang disediakan oleh perusahaan, dalam penulisan ini peneliti menggunakan alat analisis sebagai berikut :

a. Rasio Likuiditas

$$
\text { Current Ratio }=\frac{\text { Aktiva Lancar }}{\text { Hutang lancar }} \times 100 \%
$$

$$
\text { Cash Ratio }=\frac{\text { Kas }}{\text { Hutang Lancar }} \times 100 \%
$$

b. Rasio Solvabilitas

Total Debt To Equity Ratio :

$\frac{\text { Total hutang }}{\text { Modal }} \quad \mathrm{x} 100 \%$


Total Debt To Asset Ratio :

Total hutang $\quad \mathrm{x} 100$

Total aktiva

c. Rasio Aktivitas

Total Asset Turn Over:

Penjualan $\quad \mathrm{x} 100 \%$

$\overline{\text { Total aktiva }}$

Perputaran Persediaan:

Penjualan $\quad \mathrm{x} 100 \%$

$\overline{\text { Persediaan }}$

d. Rasio Profitabiitas

Return on invesment :

Laba setelah pajak $\quad \mathrm{x} 100 \%$

Total aktiva

\section{ANALISA DAN PEMBAHASAN}

\subsection{Gambaran Umum Perusahaan}

Sejarah pertambangan batubara di Tanjung Enim dimulai sejak zaman kolonial Belanda tahun 1919 dengan menggunakan metode penambangan terbuka di wilayah operasi pertama, yaitu di Tambang Air Laya. Selanjutnya mulai 1923 beroperasi dengan metode penambangan bawah tanah hingga 1940, sedangkan produksi untuk kepentingan komersial dimulai pada 1938.

\subsection{Rasio likuiditas}

Merupakan rasio yang menggambarkan kemampuan perusahaan dalam memenuhi kewajibannya (utang) jangka pendek. Artinya apabila perusahaan ditagih, perusahaan akan mampu untuk memenuhi kewajiban (utang) tersebut terutama utang yang sudah akan mampu untuk memenuhi kewajiban (utang) tersebut terutama utang yang sudah jatuh tempo .

\section{Current Ratio}

Menunjukan kemampuan perusahaan untuk menyelesaikan kewajiban jangka pendeknya.

$$
=\frac{\text { Aktiva Lancar }}{\text { Utang lancar. }} \quad \times 100 \%
$$


Tabel 1. Current ratio pada PT.Bukit Asam,Tbk tahun 2009-2011

\begin{tabular}{|c|l|c|c|}
\hline Tahun & \multicolumn{1}{|c|}{ Keterangan } & $\begin{array}{c}\text { Current } \\
\text { Ratio(\%) }\end{array}$ & Current Ratio \\
\hline 2009 & $\frac{6.783 .391}{1.380 .908} \times 100 \%$ & 491 & 4,91 \\
2010 & $\frac{6.645 .953}{1.147 .728} \times 100 \%$ & 579 & 5,79 \\
2011 & $\frac{8.859 .266}{1.912 .423} \times 100 \%$ & 463 & 4,63 \\
\hline
\end{tabular}

Sumber : PT.Bukit Asam,Tbk (data diolah 2013)

Berdasarkan tabel di atas diketahui current rasio setiap tahunnya pada PT.Bukit Asam yaitu tahun 2009 mempunyai rasio sebesar 491\% yang artinya setiap hutang lancar Rp.1 dijaminkan oleh aktiva lancar sebesar Rp. 4,91, sedangkan pada tahun 2010 mempunyai rasio 579\% yang artinya setiap hutang lancar Rp.1 dijaminkan oleh aktiva lancar sebesar Rp.5,79. Pada tahun 2011 mempunyai rasio 463\% yang artinya setiap hutang lancar Rp.1 dijaminkan oleh aktiva lancar sebesar Rp.4,63. Dilihat dari perkembangan curent rasio yang dicapai PT. Bukit Asam,Tbk dari tahun 2009 sampai tahun 2011 cenderung berfluktuasi dengan rata-rata 5,11.

\section{Cash Ratio}

Merupakan rasio untuk mengukur kemampuan sebuah perusahaan melunasi kewajiban yang harus segera dibayar dengan harta likuid yang dimiliki oleh perusahaan. Adapun perhitungan mengenai cash ratio pada PT.Bukit Asam,Tbk yaitu :

Cash rasio $=$

kas

$\mathrm{x} 100 \%$

Hutang lancar

Tabel 2. Cash ratio pada PT.Bukit Asam,Tbk. Tahun 2009-2011

\begin{tabular}{|c|c|c|c|}
\hline Tahun & \multicolumn{1}{|c|}{ Keterangan } & Cash ratio (\%) & Cash ratio \\
\hline 2009 & $\frac{4.709 .104}{1.380 .908} \times 100 \%$ & 341 & 3,41 \\
2010 & $\frac{5.045 .075}{1.147 .728} \times 100 \%$ & 439 & 4,39 \\
2011 & $\frac{6.791 .291}{1.912 .43} \times 100 \%$ & 355 & 3,55 \\
\hline \multicolumn{2}{|c|}{$\mathbf{3 , 7 8}$} \\
\hline
\end{tabular}

Sumber : PT. Bukit Asam,Tbk (data diolah 2013)

Berdasarkan tabel di atas diketahuinya cash rasio setiap tahunnya pada PT.Bukit Asam Tbk yakni tahun 2009 mempunyai rasio sebesar 341 yang artinya setiap hutang lancar Rp.1 dijaminkan oleh kas sebesar Rp. 3,41. Sedangkan pada tahun 2010 mempunyai rasio 439\% yang artinya setiap hutang lancar Rp.1 dijaminkan oleh kas sebesar Rp.4,39 . Dan pada tahun 2011 memiliki rasio sebesar $355 \%$ yang artinya setiap hutang lancar Rp.1 dijaminkan oleh kas Rp.3,55. Kenaikan rasio pada tahun 2011 disebabkan karena kas lebih besar dari hutang lancar. Dilihat dari perkembangan cash rasio yang dicapai PT. Bukit Asam,Tbk dari tahun 2009-2011 cenderung meningkat, dengan rata-rata 3,78. 


\subsection{Rasio Solvabilitas}

Menggambarkan kemampuan perusahaan dalam membayar kewajiban jangka panjangnya atau kewajiban-kewajibannya apabila perusahaan dilikuidasi baik kewajiban keuangan jangka panjang. Hasil pengukuran rasio solvabilitas didasarkan pada Total Debt To Equity Ratio dan Total Debt To Total Asset Rasio. Keadaan rasio solvabiltas PT. Bukit Asam selama tahun 2009-2011 dapat dijelaskan melalui perhitungan di bawah ini.

\section{Debt To Equity Rasio}

Total Debt To Equity Rasio merupakan suatu perbandingan antara total aktiva dengan total hutang. Setiap perubahan Total Debt To Equity Ratio PT. Bukit Asam tahun 2009-2011 adalah sebagai berikut :

\section{Total Utang X 100\%}

Modal

Tabel 3. Total Debt To Equity Ratio PT.Bukit Asam Tbk tahun 2009-2011

\begin{tabular}{|c|cc|c|c|}
\hline Tahun & \multicolumn{2}{|c|}{ Keterangan } & $\begin{array}{c}\text { Total Debt To Equity } \\
\text { Ratio(\%) }\end{array}$ & $\begin{array}{c}\text { Total Debt To } \\
\text { Equity Ratio }\end{array}$ \\
\hline 2009 & $\frac{2.292 .740}{5.402 .483}$ & x 100\% & 42 & 0,42 \\
2010 & $\frac{2.281 .451}{5.498 .225}$ & x 100\% & 41 & 0,41 \\
2011 & $\frac{3.342 .102}{6.946 .837}$ & x 100\% & 48 & 0,48 \\
\hline
\end{tabular}

\section{Sumber : PT. Bukit Asam,Tbk (data diolah 2013)}

Berdasarkan tabel di atas Total Debt To Equity Ratio pada tahun 2009 memiliki rasio yang tinggi sebesar $42 \%$ yang artinya setiap total utang sebesar Rp. 0,42 maka dijaminkan oleh ekuitas pemegang saham sebesar Rp. 1 . Sedangkan pada tahun 2010 memiliki rasio sebesar $41 \%$ yang artinya setiap total hutang sebesar Rp. 0,41 dijamin oleh ekuitas pemegang saham sebesar Rp.1 . Pada tahun 2011 memiliki rasio paling tinggi sebesar 48\% yang artinya setiap total hutang sebesar Rp. 0,48 maka dijaminkan oleh ekuitas pemegang saham sebesar Rp.1 . Kenaikan rasio pada tahun 2011 disebabkan karena meningkatnya hutang tidak lancar yang cukup tinggi . Dilihat dari perkembangan Total Debt To Equity Ratio yang dicapai PT. Bukit Asam tahun 2009-2011 cenderung meningkat dengan rata-rata perkembangan 0,43 .

\section{Total Debt To Asset Ratio}

Total Debt To Total Asset Ratio digunakan untuk mengetahui beberapa bagian aktiva yang digunakan untuk menjamin hutang. Setiap perubahan pada Total Debt To Asset Ratio PT. Bukit Asam Tbk tahun 2009-2011 adalah sebagai berikut :

Total Debt on Total Asset Ratio :

Total hutang $\quad \mathrm{x} 100 \%$

Total aktiva 
Tabel 4. Total Debt To Total Asset Ratio pada PT. Bukit Asam Tbk tahun 2009-2011.

\begin{tabular}{|c|c|c|c|}
\hline Tahun & Keterangan & $\begin{array}{c}\text { Total Debt To Asset } \\
\text { Ratio(\%) }\end{array}$ & $\begin{array}{c}\text { Total Debt To Asset } \\
\text { Ratio }\end{array}$ \\
\hline 2009 & $\frac{2.292 .740}{8.078 .578} \times 100 \%$ & 28,38 & 0,28 \\
2010 & $\frac{2.281 .451}{8.722 .699} \times 100 \%$ & 26,15 & 0,26 \\
2011 & $\frac{3.342 .102}{11.507 .104} \times 100 \%$ & 29,04 & 0,29 \\
\hline
\end{tabular}

Sumber : PT. Bukit Asam Tbk (data diolah 2013)

Berdasarkan tabel di atas Total Debt To Asset Ratio pada tahun 2009 memiliki rasio sebesar $28,38 \%$ yang artinya setiap total utang sebesar Rp. 0,28 dijamin oleh aktiva sebesar Rp. 1. Pada tahun 2010 memiliki rasio sebesar $26,15 \%$ yang artinya setiap total hutang sebesar Rp.0,26 dijamin oleh total aktiva sebesar Rp.1. Pada tahun 2011 memiliki rasio sebesar 29,04\% yang artinya setiap total utang sebesar Rp.0,29 dijamin oleh aktiva sebsar Rp.1. Peningkatan ini terjadi karena adanya peningkatan total hutang dan total aktiva. Dilihat dari perkembangan Total Debt To Asset Ratio yang dicapai PT. Bukit Asam dari tahun 2009-2011 cenderung berfluktuasi dengan rata-rata perkembangan 0,27.

\section{Rasio Aktivitas}

Analisis aktivitas digunakan untuk mengukur seberapa besar efisiensi dan efektivitas suatu perusahaan dalam mengoperasikan dana yang digunakan perusahaan untuk memperoleh pendapatan. Hasil pengukuran rasio aktivitas didasarkan pada Total Asset Turn Over dan Perputaran Persedian . Keadaan rasio aktivitas PT.Bukit Asam selama tahun 2009-2011 dapat dijelaskan melalui perhitungan dibawah ini :

\section{Total Asset Turn Over}

Total Asset Turn Over ini bertujuan untuk pengelolaan aktiva, mengukur perputaran atau pemanfaatan semua aktivitas perusahaan. Adapun perhitungan Total Asset Turn Over pada PT. Bukit Asam Tbk adalah sebagai berikut :

Total Asset Turn Over:

Penjualan $\mathrm{x} 1$ kali

Total Aktiva

Tabel 5. Total Asset Turn Over pada PT. Bukit Asam,Tbk Tahun 2009-2011 .

\begin{tabular}{|c|c|c|}
\hline Tahun & \multicolumn{1}{|c|}{ Keterangan } & $\begin{array}{c}\text { Total Asset Turn } \\
\text { Over (kali) }\end{array}$ \\
\hline 2009 & $\frac{8.947 .854}{8.078 .578}$ x $1 \mathrm{kali}$ & 1,10 \\
2010 & $\frac{7.909 .154}{8.722 .699} \times 1 \mathrm{kali}$ & 0,90 \\
2011 & $\frac{10.581 .570}{11.507 .104}$ x $1 \mathrm{kali}$ & 0,92 \\
\hline \multicolumn{2}{|l|}{ Rata-rata Total Asset Turn Over } \\
\hline
\end{tabular}

Sumber : PT. Bukit Asam,Tbk (data diolah 2013) 
Berdasarkan tabel di atas Total Aseet Turn Over pada tahun 2009 memiliki Total Asset Turn Over sebesar 1,10 kali atau setiap Rp.1 total aktiva selama setahun dapat menghasilkan penjualan sebesar Rp.1,10. Pada tahun 2010 memiliki Total Asset Turn Over sebesar 0,90 kali atau setiap Rp.1 total aktiva selama setahun dapat menghasilkan penjualan sebesar Rp.0,90. Pada tahun 2011 memiliki total asset turn over sebesar 0.92 kali atau setiap Rp.1 total aktiva selama setahun dapat menghasilkan penjualan Rp.0,92. Dilihat dari perkembangan total asset turn over yang dicapai PT. Bukit Asam,Tbk dari tahun 2009 sampai 2011 cenderung menurun dengan rata-rata perkembangan 0,97 kali.

\subsection{Perputaran Persediaan}

Perputaran persediaan ini bertujuan untuk pengelolaan aktiva, mengukur perputaran atau pemanfaatan dari semua aktivitas perusahaan. Adapun perhitungan perputaran persediaan pada PT. Bukit Asam Tbk adalah sebagai berikut :

Perputaran persediaan:

$\frac{\text { Penjualan }}{\text { Persediaan }} \quad \mathrm{x} 1$ kali

Tabel 6. Perputaran Persediaan pada PT. Bukit Asam,Tbk tahun 2009-2011.

\begin{tabular}{|l|l|c|}
\hline \multicolumn{1}{|c|}{ Tahun } & \multicolumn{1}{|c|}{ Keterangan } & Perputaran persediaan(kali) \\
\hline 2009 & $\frac{8.947 .854}{409.901} \times 1 \mathrm{kali}$ & 21,8 \\
2010 & $\frac{7.909 .154}{423.678} \times 1 \mathrm{kali}$ & 18,6 \\
2011 & $\frac{10.581 .570}{644.833} \times 1 \mathrm{kali}$ & 16,4 \\
\hline \multicolumn{2}{|l|}{ Rata-rata perputaran persediaan } \\
\hline
\end{tabular}

Sumber : PT. Bukit Asam Tbk (data diolah 2013)

Berdasarkan tabel di atas perputaran persediaan yang tertanam dalam keseluruhan aktiva pada tahun 2009 memiiki rasio sebesar 21,8 kali atau setiap Rp.1 dapat menghasilkan penjualan sebesar Rp. 21,8. Pada tahun 2009 memiliki rasio sebesar 18,6 kali atau setiap Rp.1 total aktiva tetap dapat menghasilkan penjualan sebesar Rp. 18,6. Pada tahun 2011 memiliki rasio sebesar 16,4 kali yang artinya setiap Rp.1 total aktiva tetap dapat menghasilkan penjualan sebesar Rp. 16,4 . Dilihat dari perkembangan perputaran persdiaaan yang dicapai PT. Bukit Asam Tbk di tahun 2009 sampai 2011 cenderung menurun dengan rata-rata perkembangan 18,9 kali.

\subsection{Rasio Profitabilitas}

Menggambarkan kemampuan perusahaan mendapatkan laba melalui semua kemampuan, dan sumber yang ada selama periode tertentu . Keadaan Rasio Profitabilitas PT. Bukit Asam Tbk tahun 2009 sampai 2011 dapat dijelaskan sebagai berikut :

\section{Return on Investment}

Menggambarkan kemampuan dari modal yang diinvestasikan dalam keseluruhan aktiva untuk menghasilkan keuntungan.

Return on Invesment :

laba setelah pajak $\quad \mathrm{x} 100 \%$

Total aktiva 
Tabel 7. Return On Invesment pada PT. Bukit Asam,Tbk tahun 2009-2011 .

\begin{tabular}{|c|l|c|}
\hline Tahun & \multicolumn{1}{|c|}{ Keterangan } & Perputaran persediaan(kali) \\
\hline 2009 & $\frac{8.947 .854}{409.901} \times 1 \mathrm{kali}$ & 21,8 \\
2010 & $\frac{7.909 .154}{423.678} \times 1 \mathrm{kali}$ & 18,6 \\
2011 & $\frac{10.581 .570}{644.833} \times 1 \mathrm{kali}$ & 16,4 \\
\hline
\end{tabular}

Sumber : PT. Bukit Asam Tbk (data diolah 2013)

Berdasarkan tabel di atas perputaran persediaan yang tertanam dalam keseluruhan aktiva pada tahun 2009 memiiki rasio sebesar 21,8 kali atau setiap Rp.1 dapat menghasilkan penjualan sebesar Rp. 21,8. Pada tahun 2009 memiliki rasio sebesar 18,6 kali atau setiap Rp.1 total aktiva tetap dapat menghasilkan penjualan sebesar Rp. 18,6. Pada tahun 2011 memiliki rasio sebesar 16,4 kali yang artinya setiap Rp.1 total aktiva tetap dapat menghasilkan penjualan sebesar Rp. 16,4 . Dilihat dari perkembangan perputaran persdiaaan yang dicapai PT. Bukit Asam Tbk di tahun 2009 sampai 2011 cenderung menurun dengan rata-rata perkembangan 18,9 kali.

\subsection{Rasio Profitabilitas}

Menggambarkan kemampuan perusahaan mendapatkan laba melalui semua kemampuan, dan sumber yang ada selama periode tertentu. Keadaan Rasio Profitabilitas PT. Bukit Asam Tbk tahun 2009 sampai 2011 dapat dijelaskan sebagai berikut :

\section{Return on Investment}

Menggambarkan kemampuan dari modal yang diinvestasikan dalam keseluruhan aktiva untuk menghasilkan keuntungan.

Return on Invesment = laba setelah pajak $\quad$ x 100\%

$$
\text { Total aktiva }
$$

Tabel 7. Return On Invesment pada PT. Bukit Asam,Tbk tahun 2009-2011 .

\begin{tabular}{|c|c|c|c|}
\hline Tahun & \multicolumn{1}{|c|}{ Keterangan } & $\begin{array}{c}\text { Return On } \\
\text { Invesment(ROI) }(\%)\end{array}$ & $\begin{array}{c}\text { Return On } \\
\text { Invesment }\end{array}$ \\
\hline 2009 & $\frac{2.727 .734}{8.078 .578} \times 100 \%$ & 33,76 & 0,33 \\
2010 & $\frac{2.008 .891}{8.722 .699} \times 100 \%$ & 23,03 & 0,23 \\
2011 & $\frac{3.085 .836}{11.507 .104} \times 100 \%$ & 26,81 & 0,26 \\
\hline
\end{tabular}

Sumber : PT. Bukit Asam Tbk (data diolah 2013)

Berdasarkan tabel di atas return on investment yang dicapai perusahaan pada tahun 2009 memiliki rasio sebesar 33,76\% yang artinya setiap total aktiva Rp.1 menghasilkan laba setelah pajak sebesar Rp. 0,33. Tahun 2010 memiliki rasio sebesar 23,03\% yang artinya setiap total aktiva Rp.1 
menghasilkan laba setelah pajak sebesar Rp. 0,23. Pada tahun 2011 memiliki rasio sebesar 26,81 yang artinya setiap total aktiva sebesar Rp.1 menghasilkan laba sebelum pajak sebesar Rp.0,36. Dilihat dari perkembangan Return On Invesment yang dicapai PT. Bukit Asam,Tbk dari tahun 2009 sampai 2011 cenderung berfluktuasi dengan rata-rata perkembangan 0,27 .

\subsection{Analisis Rasio Keuangan}

Suatu analisa untuk mengetahui suatu keadaan dan perkembangan finansial dari perusahaan yang bersangkutan dan merupakan kegiatan membandingkan angka-angka yang ada dalam laporan keuangan dengan cara membagi satu angka dengan angka lainnya.

\section{Rasio Likuiditas}

Tingkat likuiditas PT. Bukit Asam Tbk tahun 2009 sampai dengan 2011 menunjukkan prestasi atau kinerja yang cukup baik yang dapat dilihat dari :

a. Current Ratio

Current Rasio dapat dikatakan baik, rasio paling rendah terjadi pada tahun 2011 yaitu sebesar 463\% . Rasio yang paling baik terjadi pada tahun 2010 yaitu sebesar 579\% . Current Rasio dapat dikatakan cukup baik karena mempunyai rasio cenderung berfluktuasi dengan rata-rata sebesar 5,11

b. Cash Rasio

Cash Rasio dapat dikatakan baik dari tahun 2009 sampai 2011. Rasio yang paling rendah terjadi pada tahun 2009 yaitu sebesar 349 . Rasio yang baik terjadi pada tahun 2010 yaitu sebesar 462 . Cash Rasio dapat dikatakan baik karena mempunyai rasio cenderung meningkat dengan peningkatan sebesar 3,78. Dengan kata lain perusahaan ini mampu memenuhi kewajiban jangka pendek dan likuid

\section{Rasio Solvabilitas}

Tingkat Rasio Solvabilitas PT. Bukit Asam Tbk tahun 2009 sampai 2011 menunjukkan perstasi atau kinerja yang cukup baik pada Total Debt To Equity Ratio dan cukup baik pada Total Debt Asset Ratio selama tiga tahun terakhir ini yang dapat dilihat dari :

a. Total Debt To Equity Ratio

Total Debt To Equity Ratio yang paling tinggi dan paling buruk terjadi pada tahun 2011 sebesar 48\% . Rasio paling rendah dan paling baik terjadi pada tahun 2010 yaitu sebesar 41\%. Debt To Equity Rasio dikatakan kurang baik karena mempunyai rasio yang menurun dengan rata-rata rasio sebesar 0,43 tetapi perusahaan ini termasuk solvabel .

b. Total Debt to Total Asset Ratio

Total Debt to Total Asset Ratio yang paling tinggi dan paling buruk terjadi pada tahun 2011 yaitu sebesar $29,04 \%$. Rasio yang paling rendah dan paling baik terjadi pada tahun 2010 yaitu sebesar $26,15 \%$. Total Debt to Total Asset Ratio dikatakan kurang baik karena mempunyai rasio yang cenderung menurun dengan rata-rata rasio sebesar 0,27. Tetapi perusahaan ini termasuk solvabel

\section{Rasio Aktivitas}

Tingkat rasio aktivitas PT. Bukit Asam,Tbk tahun 2009 sampai 2011 menunjukkan prestasi atau kinerja yang kurang baik selama tiga tahun terakhir ini yang dapat dilihat dari :

a. Total Asset Turn Over

Total Asset Turn Over pada perusahaan ini untuk tahun 2009 sampai 2011 dikatakan baik. Total Asset Turn Over yang paling tinggi terjadi pada tahun 2009 yaitu sebesar 1,10 kali sedangkan Total Asset Turn Over yang paling rendah terjadi pada tahun 2010 yaitu sebesar 0,90 kali . Total Asset Turn Over dapat dikatakan kurang baik disebabkan mempunyai rasio cenderung menurun dengan rata-rata penurunan sebesar 0,09. 
b. Perputaran persediaan

Tingkat aktivitas pada perusahaan ini pada tahun 2009 sampai 2011 melalui perhitungan perputaran persediaan dikatakan cukup baik. Perputaran persediaan yang paling tinggi dan paling baik terjadi pada tahun 2009 yaitu sebesar 21,8 kali, sedangkan perputaran persediaan paling rendah terjadi pada tahun 2011 yaitu sebesar 16,4 kali. Perputaran persediaan dapat dikatakan kurang baik karena penurunan kembali terjadi dari tahun 2009 sampai tahun 2011 dengan ratarata penurunan sebesar 2,7.

\section{Rasio Profitabilitas}

Tingkat Rasio Profitabilitas PT. Bukit Asam,Tbk tahun 2009 sampai 2011 menunjukkan prestasi atau kinerja yang cukup baik rasio selama tiga tahun terakhir ini dapat dilihat dari :

Return On Investment (ROI)

Tingkat profitabilitas rasio pada perusahaan ini pada tahun 2009 sampai 2011 melalui perhitungan Return On Investment dapat dikatakan baik. Return On Investment yang paling tinggi dan paling baik terjadi pada tahun 2009 yaitu sebesar 33,76\%. Sedangkan Return On Invesment paling rendah terjadi pada tahun 2010 yaitu sebesar 23,03\%. Return On Investment dikatakan baik disebabkan mempunyai rasio yang cenderung berfluktuasi dengan rata-rata peningkatan sebesar 3,4\%.

\section{KESIMPULAN DAN SARAN}

Dari hasil analisis yang dibahas pada bab-bab sebelumnya, berdasarkan data-data yang diperoleh dari PT. Bukit Asam,Tbk maka penulis dapat menarik kesimpulan sebagai berikut :

1. Ditinjau dari sudut likuiditas PT. Bukit Asam Tbk selama tiga tahun yaitu dari tahun 2009 sampai 2011 menunjukkan kinerja keuangan yang baik, dapat dilihat dari current ratio dan cash ratio yang cenderung meningkat selama tiga tahun terakhir, dengan kinerja keuangan perusahaan yang baik, dan perusahaan likuid serta memiliki prospek di masa akan datang maka berpengaruh baik bagi para investor untuk menanamkan modalnya pada PT.Bukit Asam,Tbk .

2. Ditinjau dari sudut solvabilitas, PT. Bukit Asam Tbk selama tiga tahun yaitu dari tahun 2009 sampai tahun 2011 menunjukkan tingkat kinerja keuangan yang baik. Dapat dilihat dari Total Debt To Equity Ratio dan Total Debt Total Asset Ratio, dengan kinerja keuangan perusahaan yang baik, dan perusahaan yang solvabel serta memiliki prospek di masa yang akan datang maka berpengaruh baik bagi para investor untuk menanamkan modalnya pada PT. Bukit Asam,Tbk .

3. Ditinjau dari sudut aktivitas, PT. Bukit Asam Tbk selama tiga tahun yaitu dari tahun 2009 sampai tahun 2011 menunjukkan tingkat kinerja keuangan yang cukup baik. Dapat dilihat dimana kurang baiknya perusahaan dalam dari Total Asset Turn Over dan Perputaran Persediaan cenderung mengalami penurunan selama tiga tahun terakhir mengoperasikan dana untuk memperoeh pendapatan secara efisiensi dan efektivitas. Walaupun kondisi keuangan perusahaan yang ditinjau dari rasio aktivitas kurang baik, bagi para investor tidak perlu merasa cemas untuk menanamkan modal pada PT. Bukit Asam,Tbk karena kondisi perusahaan ini masih dalam kondisi stabil .

4. Ditinjau dari sudut profitabilitas PT. Bukit Asam Tbk selama tiga tahun yaitu dari tahun 2009 sampai tahun 2011 menunjukkan kinerja keuangan yang cukup baik. Dapat dilihat dari Return On Invesment yang cenderung berfluktuasi selama tiga tahun terakhir. 


\subsection{Saran}

1. Mempertahankan kondisi dan kinerja keuangan perusahaan secara likuiditas yang baik seperti sekarang, karena perusahaan likuid dan memiliki prospek yang baik di masa akan datang.

2. Mempertahankan kondisi dan kinerja keuangan perusahaan secara solvabilitas yang baik seperti sekarang karena perusahaan solvabel dan memiliki prospek yang baik di masa akan datang .

3. Meningkatkan aktivitas dengan cara meningkatkan penjualan dan menurunkan total aktiva agar kinerja keuangan perusahaan dalam mengoperasikan dana dapat lebih efektif dan efisien untuk memperoleh pendapatan yang lebih baik.

4. Meningkatkan profitabilitas dengan cara meningkatkan laba setelah pajak dan menurunkan total aktiva, dengan mengurangi biaya usaha relatif lebih besar daripada berkurangnya pendapatan dari penjualan .

\section{DAFTAR PUSTAKA}

Baridwan Zaki, 2004 intermediate accounting.

Harahap, Syafri Sofyan, 2004. Analisa laporan keuangan .

Husnan, Suad. 2003. Dasar-Dasar manajemen keuangan.edisi keempat. Yogyakarta.

Ikatan Akuntan Indonesia(IAI).standar akuntansi keuangan, 2001

Ikatan Akuntan Indonesia (IAI), dalam PSAK No.1 Paragraf 07

Budiawan. 2009 . kamus akuntansi . 2000.

Mulyadi, 2001. penilaian kinerja.

Syafarudin

S. Munawir, Drs., Analisis Laporan Keuangan, Liberty, Yogyakarta.

S. Munawir,2004 Analisis Laporan Keuangan, Liberty, Yogyakarta .

western dan coupelan dalam harian dini , 2000

www.bukitasam.co.id 
Sengaja Dikosongkan 